\title{
The Curious Case of Saloma's Legacy: Documenting the Works of Biduan Negara
}

\author{
Ahmad Kamal Basyah Sallehuddin, Abdul Walid Ali, Muhammad Qawiem \\ Hamizan
}

To Link this Article: http://dx.doi.org/10.6007/IJARBSS/v11-i1/8414

DOI:10.6007/IJARBSS/v11-i1/8414

Received: 03 November 2020, Revised: 29 November 2020, Accepted: 18 December 2020

Published Online: 10 January 2021

In-Text Citation: (Sallehuddin et al., 2021)

To Cite this Article: Sallehuddin, A. K. B., Ali, A. W., \& Hamizan, M. Q. (2021). The Curious Case of Saloma's Legacy: Documenting the Works of Biduan Negara. International Journal of Academic Research in Business and Social Sciences, 11(1), 96-105.

\section{Copyright: @ 2021 The Author(s)}

Published by Human Resource Management Academic Research Society (www.hrmars.com)

This article is published under the Creative Commons Attribution (CC BY 4.0) license. Anyone may reproduce, distribute, translate and create derivative works of this article (for both commercial and non-commercial purposes), subject to full attribution to the original publication and authors. The full terms of this license may be seen at: http://creativecommons.org/licences/by/4.0/legalcode

\section{Vol. 11, No. 1, 2021, Pg. 96 - 105}

Full Terms \& Conditions of access and use can be found at http://hrmars.com/index.php/pages/detail/publication-ethics 


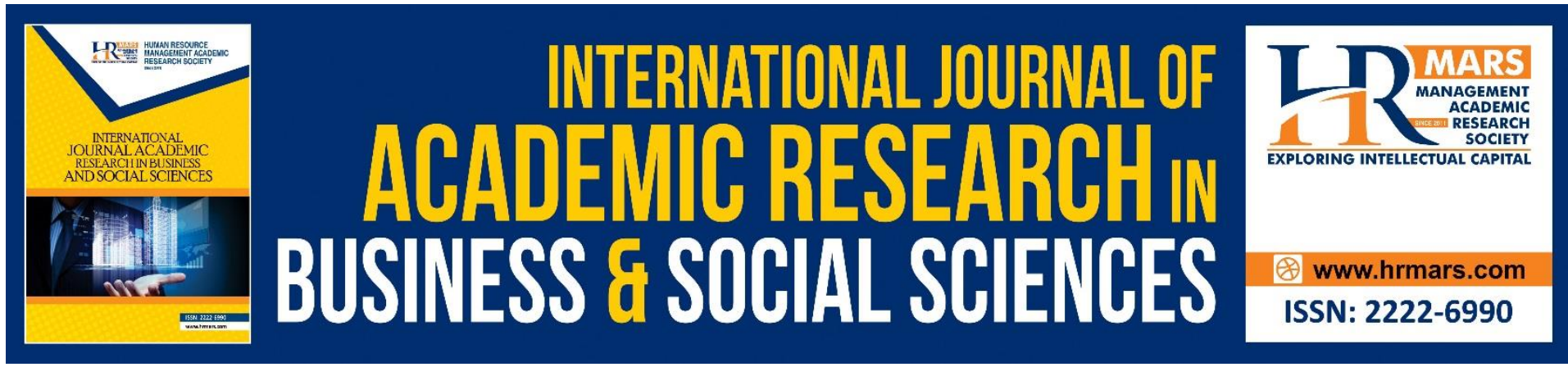

\title{
The Curious Case of Saloma's Legacy: Documenting the Works of Biduan Negara
}

\author{
Ahmad Kamal Basyah Sallehuddin \\ Faculty of Film, Theatre and Animation, Universiti Teknologi MARA (UITM), Selangor Branch, \\ Puncak Perdana Campus, 40150 Shah Alam, Selangor. \\ Email: akamalbasyah@uitm.edu.my
}

\begin{abstract}
Abdul Walid Ali
Faculty of Applied and Creative Arts, Universiti Malaysia Sarawak (UNIMAS), 94300 Kota

Samarahan, Sarawak.

Email: aawalid@unimas.my
\end{abstract}

Muhammad Qawiem Hamizan

Faculty of Applied and Creative Arts, Universiti Malaysia Sarawak (UNIMAS)

94300 Kota Samarahan, Sarawak.

Email: hmqawiem@unimas.my

\begin{abstract}
Puan Sri Datin Amar Salmah Ismail, known professionally as Saloma, is Malaysia's own Biduan Negara. Even though most people today recognised her as the significant other of Tan Sri Dato' Amar (Dr) P. Ramlee, Saloma's popularity as one of Malaysia's prominent singers is undeniable. However, given her position as Biduan Negara of Malaysia, the documentation of her legacy has reflected anything but, and this article aims to explain the problems plaguing efforts to properly document Saloma's legacy. The list of recordings has been incomplete for years, even though attempts were made to fortify her legacy by re-releasing her recordings after her demise. Her participation on television programmes and radio recordings were also not properly documented. Her vast collections of couture have been in the storage for almost 30 years, and only a handful of attires were exhibited to the public. At the same time, her handful of appearances on films are still accessible, even though some of her earlier films are unsalvageable. Serious efforts must be taken to properly document Saloma's legacy, as Biduan Negara is not just an ordinary title for a singer who contributed so much to Malaysia's arts.
\end{abstract}

\section{Introduction}

Biduan Negara Puan Sri Datin Amar Saloma, or her real name Salmah Ismail, was born on January 22, 1935, in Pasir Panjang, Singapore. She started singing professionally at the tender age 13, under the tutelage of her stepfather, Mum Yusoff, a keroncong musician. Mum introduced Salmah to his colleagues at Radio Malaya; on a fateful day, when Rokiah Wanda, 
a renowned singer at that time, failed to appear at the scheduled broadcast for Radio Malaya, young Salmah was asked to fill in, and a young star was born. She made more singing appearances with Radio Malaya's in-house orchestra; alas, her singing career did not take off as what she had wanted, so she accepted an offer from Nusantara Film Productions Limited. As a film actress, Salmah appeared in a number of films, such as Pelangi, Perkahwinan Rahasia, Chinta Murni, Norma, and Sesal Ta' Sudah. After she gave birth to her only child in 1953 (and subsequent divorce from her first husband, A.R. Tompel), Salmah joined a performance troupe and toured Sarawak, Brunei and North Borneo. Upon her return, Salmah was offered a recording deal from Pathe Company (an EMI subsidiary). Her first recordings were "Pandang Kasih" and "Jika Tak Berjumpa". Under Pathe, Salmah began to release more hit records, such as "Burong Ponggok", "Senyuman Ta' Berbalas", "Jauh Malam", "Menanggung Rasa", "Hujan Lebat" and "Inang Baru", her first cooperation with the legendary P. Ramlee, who would later marry her in 1961. In the 1960s, Saloma's popularity soared to a higher echelon; she still recorded for EMI Singapore (rechristened from Pathe, and remain signed to the company until 1977) and appeared in Seniman Bujang Lapok. She relocated to Kuala Lumpur, and released more hit recordings such as "Biarlah Aku Pergi", "Selamat Pengantin Baru", "Bila Larut Malam", "Bunga Tanjong", "Yang Di Tunggu Tak Tiba" and "Aku Dia Dan Lagu". Meanwhile, she continued to act in films (Sabaruddin Tukang Kasut and Ahmad Albab), this time under Shaw Organisation's Setudio Merdeka. Simultaneously, she became a regular performer on both RTS (in Singapore) and RTM, appearing in TV programmes such as Istana Pesta, Kalong Senandong, and Konsert Perdana Bersama Orkestra RTM. After the tragic passing of P. Ramlee in 1973, Saloma returned to recording 1974 after a lengthy period of grief and depression that took a toll on her health; she released Airmata Di Kuala Lumpur and Sesudah Suboh in the same year. The former contained P. Ramlee's final composition (the title track) and their final duet, "Uda Dan Dara". In 1975, she released Kelohan Saloma, her final album for EMI; she also appeared in her weekly programme on RTM, Saloma Show, and continued performing with Orkestra RTM. In 1978, SENIMAN awarded Saloma with the honourable title "Biduan Negara"; at this time, Saloma rarely made public appearances as she was secretly battling blood cancer. In 1981, she released her final album Biduan Negara Saloma, this time under the independent company Indra Rekod. It was reported that Indra Rekod gifted Saloma a red Mitsubishi Colt and \$20,000.00 in cash when she agreed to be the first signee of the Bumiputera company, thus turning this into the most lucrative recording deal at that time. After a long battle, she succumbed to her illness (reported as liver failure associated with jaundice) on April 25, 1983 and was buried at the Jalan Ampang Muslim Cemetery. In this paper, the authors identified and grouped the many facets of Saloma's legacies as a singer, an actress and a fashion icon, and later distinguished and explained how her full legacy had been overlooked and went underappreciated, even though some efforts were taken to appreciate her commercial recordings.

\section{Related Works}

For a legendary singer of her stature, Saloma could be considered as the counterpart of a number of renowned international singers, such as Ella Fitzgerald, Peggy Lee, Doris Day, to name a few. Unfortunately, unlike Fitzgerald, Lee or Day (where their respective legacy has been treasured and celebrated in their home country), Saloma's contribution to the performing arts and music industry in this country has been anything but properly documented, appreciated and upheld. As the legally wedded spouse of the late Tan Sri Datuk Amar (Dr) P. Ramlee, she was automatically allotted (albeit posthumously) the honorary title 
"Puan Sri Datin Amar", but nothing else. For the record, the 5th Yang di-Pertuan Agong, AlSultan Al-Mu'tassimu Billahi Muhibbuddin Tuanku Al-Haj Abdul Halim Mu'adzam Shah ibni Almarhum Sultan Badlishah bestowed the honorary Ahli Mangku Negara to Saloma in 1974. As previously mentioned, Saloma was recognised as "Biduan Negara" by the Persatuan Seniman dan Seniwati Malaysia (SENIMAN) in November 1978. After her passing, a minor road off Jalan Ampang and next to Menara Public Bank was rechristened as "Jalan Saloma", and in 2020, a pedestrian bridge connecting Lorong Raja Muda Musa 3 in Kampung Baru and Jalan Saloma was christened as "Saloma Link" (or "Pintasan Saloma"). A project commissioned by Kampong Bharu Development Corporation, the scenic 370 metres bridge illuminated with colourful LED lights is currently a popular spot among local tourists for its "Instagrammable" feature, especially after the ease of Movement Control Order. In the past, a local businessman, Tan Sri Syed Yusof Syed Nasir opened a fine dining restaurant named Saloma Bistro and Theatre Restaurant, which was strategically located on Jalan Ampang. Opened in 2003, it was named in honour of Saloma; alas, the aforesaid fine dining restaurant closed down in 2017 due to land lease agreement issues. More recently, her niece, actress and director Melissa Saila produced a two-part biopic, Saloma: Mencuri Guruh and Saloma: Pandang Kaseh, which was aired exclusively on Astro channels. Featuring award-winning actress Nabila Huda as Saloma, this biopic was embroiled in a controversy when the family members of Saloma's first husband, the late A. R. Tompel (a celebrated comedian and director), were exasperated with the way Tompel was portrayed in Saloma: Mencuri Guruh. Another project was completed by retro singer Ahmad Fauzee Samad, who published a coffee table book entitled Saloma. The book, which covered Saloma's career from the beginning until 1959, was published in 2011 by Fauzee's own company, AF Cendana Sdn. Bhd. A second volume of the book is currently at works. Other than that, it is best to say that appreciation to Saloma's legacy has been far and in between.

\section{Saloma's Recordings: EMI Singapore and Indra Rekod}

In 1954, after a few years of performing prolifically in radio shows, funfairs and nightclubs, Saloma recorded her first songs for Pathe Company, an EMI Records subsidiary originated from Britain. She released her debut album (in an SP, 78 rpm record format), with two songs: "Pandang Kaseh" (written by Rahmat Ali and Ismadi) and "Jika Tak Berjumpa" (written by S.Hussein Bagushir and Wan Chu). As her popularity increased, Saloma began to record more frequently; all these recordings were released in the usual SP, 78 rpm record, or a compilation album featuring other singers contracted under Pathe Company such as Abdullah Chik, Normadiah, Nona Asiah, P. Ramlee, Lena, Julia, Zeera Agus (or Zaharah Agus) and R. Azmi, to name a few. It wasn't until 1957 when Parlophone, another EMI subsidiary, released her debut full-length 10-inch vinyl LP record entitled Dendang Saloma (Saloma Sings), featuring songs such as "Inang Baru", "Putus Harapan", "Hujan Lebat", "Lenggang Kangkong Bharu" and many others. Saloma consistently released albums in the aforesaid format, unlike her counterparts. Alas, it is not known how many albums Saloma had released in the first 10 years of her career, as EMI Malaysia Sdn Bhd, the local distributor of artists signed to EMI Singapore Pte Ltd., was only established in 1966, thus the non-existent of proper documentation. Once EMI opened a local branch in Kuala Lumpur, the system of documenting album releases was more systematic and reliable. Throughout the 1960s, Saloma's songs were released in SP, EP (containing 4 songs; this was the most popular format that most recording companies used to release songs from Malaysian and Singaporean singers), and LP. It wasn't until when EMI 
Malaysia began to seriously cataloguing all albums that Saloma's list of albums was documented, alas most albums prior to 1970 were not listed.

According to Safee Yusof, Catalogue Manager (Domestic Department) for EMI Malaysia and Warner Music Malaysia, Saloma's albums released in the 1970s turned out to be her best-selling albums in her illustrious career. As a result, these albums were documented as part of their EMI Malaysia catalogue, even though Saloma was contracted under EMI Singapore. Moreover, EMI Malaysia did its best to honour Saloma's legacy with only limited resources in their vault. On the first anniversary of her passing in 1984, EMI Malaysia released Saloma: Kau Masih Dikenang Volume 1 and Saloma: Kau Masih Dikenang Volume 2 in both LP and cassette formats; all songs were compiled from her 1970s recordings (done after the passing of P. Ramlee) and early materials from compilation albums. In 1988, EMI Malaysia released another compilation, Koleksi 16 Lagu-lagu Terbaik containing songs almost similar to Kau Masih Dikenang. Later, in a joint venture project with EMI Toshiba and Bomba Records, Saloma - Bunga Malaysia was released exclusively in compact disc in Japan (marking for the first time that recordings of Saloma were released in this format), featuring 17 songs similar to the previously mentioned compilations. Safee also explained that in 1991, EMI Malaysia sent a number of master tapes that they were able to secure from the vault of EMI Singapore (as well as the ones owned by EMI Malaysia) to the famed recording studio in London, Abbey Road Studio. The master tapes underwent digital remastering using Cedar Enhancement restoration under the tutelage of David Reckless, senior remastering sound engineer from Abbey Studios. Thus, all the remastered songs were released under Siri Kenangan Abadi Volume IV and Siri Kenangan Abadi Volume $V$ in 1992 (the first three volumes under this series were recordings of P. Ramlee's). However, there are many songs left in EMI Singapore's vault that were not utilised or submitted for the same process due to budget constraint. This is why throughout the years starting from 1996, these remastered songs (alongside songs from the previous compilations released in 1980s) were repackaged and rereleased under different titles such as Jimat (1995); Siri Perdana: Saloma - Primadona (1997); Saloma (2003); Saloma (2011); Koleksi Klasik Nasional (2007); Lagenda Hit Puan Sri Saloma (2011); Saloma (2012). However, these songs were mastered locally, thus the results may not be as excellent as the songs remastered in the famed Abbey Studios. Sadly, some local companies were taking advantage by releasing unauthorised Saloma recordings obtained from film recordings and radio shows. Saloma's final album, Biduan Negara Saloma, which was released under independent, Bumiputera company Indra Rekod has been out-of-print since 1983; so far, the legal owner of the master tape is yet to be known as the company had folded in 1982. Bootleg recordings of Biduan Negara Saloma (featuring her final hits such as "Lagu Anak Rantau" and "Kembara Rasa"), as well as other materials not available in EMI Malaysia's vault, are sold openly in flea markets around Malaysia. It is imperative to inform that EMI Malaysia had ceased operation in 2007, and all recordings were temporarily controlled and released by Warner Music Malaysia. At this time, all master tapes (in quarterinch tapes, CD-R and DAT formats) were sent to EMI Hong Kong's office as the recordings were owned by EMI Asia. Safee added that some master tapes may still be available in EMI Singapore's storage, but no further action is taken in handling these priceless gems. In 2014, Universal Music took over the proprietorship of EMI's recordings as the former bought out the owners of EMI in the UK. Universal Music Malaysia is yet to work on the proper list of Saloma's discography starting from 1954 to 1975, as the company's focus in this region is to work on young and fresh talents from around the country. Nevertheless, some loyal Saloma 
fans are compiling the list comprehensively; the list can be viewed on Discogs website, as well as muziknusantara.com and rateyourmusic.com websites.

\section{Saloma's Recordings: Radio Televisyen Malaysia}

Saloma's recordings are not only limited to commercial releases, but also for radio and TV programmes. The best source to search for these recordings is Rakam Khanah P. Ramlee, located in Angkasapuri, the main office for Radio Televisyen Malaysia (henceforth to be referred to as RTM). In Rakam Khanah P. Ramlee, most songs from Saloma are kept in the system by categorising them under genres and sources. Noraini Ibnu, Deputy Director of Rakam Khanah P. Ramlee, mentioned that these songs were stored digitally to ensure their safety and preservation for years to come. The songs were transferred from original sources - EP, LP and compact disc. The original sources were later kept in a safeguarded shelf administered by assistant librarians. To locate a song, you may enter a keyword in the search engine provided; the search for "Saloma" returned with hundreds of songs in the system. Unfortunately, the songs were listed under her name, not necessarily from their original sources. The information of the source is included, but not for every song listed. In order to search for an album, one must be able to get the correct title, like Persembahan Saloma or Kelohan Saloma. This is problematic, as no one has the complete list of Saloma's discography as detailed in the previous paragraph. Nevertheless, Rakam Khanah P. Ramlee had done its best to preserve all Saloma's songs accumulated over the years. Besides her recordings for commercially released materials under EMI and Indra Rekod, Rakam Khanah P. Ramlee also preserve Saloma's exclusive recordings for RTM - these were recordings done with Orkestra RTM and Kombo RTM for broadcasting purpose only, not for sale to the public members. Titles such as Persembahan Saloma, Saloma Sings, Rampaian No. 3, Konsert Perdana 1974 and Seri Paduka Baginda were kept in both hard copy and digital versions. In addition to her staple hits, other rare and evasve songs were found and kept in the system, such as "Manusia Musti Mati", "Hingga Bersua Lagi", "Chari Sayang" and "Chinchin Ku Ini". On YouTube, an account under the name "ud.000" (administered by Saloma's loyal fan only known as Yudhie from Sarawak) occasionally share some other rare recordings from Saloma, originated from EPs and LPs from the user's personal collection; some other songs were also streamed on a website named muziknusantara.com, which is based in Singapore. Alas, the recordings stored in Rakam Khanah P. Ramlee are not accessible to the public, who may show interest in buying or collecting them as private possession.

Throughout her career, Saloma had participated in a number of variety shows and concerts on television. She appeared regularly on shows such as Kalong Senandong and Istana Pesta on RTS (Radio Television Singapore); later, as she was based in Kuala Lumpur, Saloma became a regular staple on RTM (Radio Televisyen Malaysia) shows on both television and radio. For television recordings, RTM retains most recorded television shows at its own Unit Perpustakaan TV. Unfortunately, due to lack of awareness on entertainment intellectual properties, a number of these shows are destroyed or imperceptible such as Saloma Show (featuring a number of guest performers such as Julie Sudiro, Andre Goh, Sarena Hashim and her own children, Zakiah and Sabaruddin), Hiburan Malam Minggu Sarena Hashim (Saloma reciprocated Sarena's invitation by appearing on an episode as s special guest star), and a Christmas special, appearing alongside the late Zain Azman and The Solianos. However, there were a number of shows salvaged and transferred to digital tapes in order to preserve its contents, thanks to the hardworking team of library assistants under the guidance of Mazidah Abdul Rahman, Deputy Director of Unit Perpustakaan TV. Some of the titles including 
Anekarama (1972); Konsert Perdana Orkestra RTM 1973 (1973); Malam Seniman Silam (1975); Ramlee (1977); Puspawarna (1978); Anekaria (1982); Aidilfitri (1983); and Puspawarna (1983). At the moment, there is no proper document compiling a comprehensive list of Saloma's television performance as well, as opposed to other EMI superstars such as Sharifah Aini and Sudirman. At the same time, the audio versions of her appearances on Saloma Show and Hiburan Malam Minggu Sarena Hashim were uploaded on YouTube; for the former, the audio recordings were shared by YouTube user Wardi Klasik (featuring her renditions of "Biarlah Aku Pergi" in a rock arrangement; "Madah Pujangga" in a jazzier arrangement; a rare English number "There'll Never Be Another You", and duets with Andre Goh and Julie Sudiro), while the latter was shared by YouTube user sarenafanclub09 (featuring a medley of Saloma hits "Kalau Abang Cinta"/"Apa Ertinya Janji"/"Mari Jalan Bersama" as a duet with Sarena Hashim and her dramatic solo rendition of Neil Sedaka's hit "Solitaire"). It is tragic knowing that future generations of fans and Malaysians are unable to watch these mesmerising performances on the screen.

In 1990, RTM produced a documentary style-variety show with 4 episodes entitled Nostalgia Biduan Negara Saloma, featuring Siti Haslinda Abdul Hamid, or Shashah Hamid (Saloma's niece), as Saloma; other performers taking part in this high-budgeted project including Saloma's other family members: Mariani (Mariam Ismail), her elder sister; Mimiloma (Aminah Ismail), her younger half-sister; Melissa Saila (Melisa Mohd. Alias), her niece; Dian P. Ramlee (Salfarina Mum), her daughter; Rozita Rohaizad (Siti Roswita Hamid), her niece; Nasir P. Ramlee (Teuku Mohammad Nasir Teuku Zakaria), her stepson; and Armali Aman Ramli, her son. In addition, a mixture of new and legendary performers was also taking parts in the ambitious television programme: Panca Sitara, Kassim Masdor, Zain Azman, Liza Aziz, Raja Ema, Ramlah Ram, Wann, Jalil Hamid, Yusni Hamid, and many more. Through the years, only a handful of programmes were produced to celebrate the legacy of Saloma, but these programmes were not receiving publicities in the media. Moreover, only RTM is productive in producing Saloma-related programmes; other private television stations such as TV3, NTV7, Astro Ria, and Astro Prima are yet to honour Saloma's legacy.

\section{Saloma as Fashion Icon and Her Couture Collection}

Saloma's influence in the local fashion scene must not be overlooked. She became a trendsetter by wearing a number of fusion kebayas, Bodo dresses, evening dresses and cheongsams designed by Nona Asiah, Raja Zai, Chempaka Booty, Bob Tan and Abol, as well as dresses designed by herself while appearing on films, television shows, stage performances and nightclub appearances. Plenty of these dresses survived and a few are currently on display at the P. Ramlee Memorial House in Taman P. Ramlee (formerly Taman Furlong), Setapak, Kuala Lumpur. Only a handful of Saloma's memorabilia are displayed, and there are no plans by the National Archives of Malaysia (Arkib Negara Malaysia) to open a memorial for Saloma, even though at one time Saloma was more popular than P. Ramlee himself. Still, in 2017, Muzium Negara hosted an exhibition entitled "Pameran Ikon Fesyen Retro Saloma (Saloma, Retro Fashion Icon)", curated by Syahrul Ab Ghani, head curator of National Textile Museum. Syahrul was assisted by none other than Siti Haslinda Abdul Hamid (known as Shashah Hamid), a renowned supermodel and image advisor, and a niece of Saloma. For the record, Shashah was co-raised by her famous aunt and had lived together with both P. Ramlee and Saloma. In a personal interview interview, Shashah admitted that a plethora of clothes belonging to both P. Ramlee and Saloma were donated to the National Archives of Malaysia. These clothes were kept in a number of storages (at various locations) owned by the 
aforementioned government agency, and nothing is planned on how these clothes can be used for exhibition. When approached by the National Textile Musuem, Shashah contributed her ideas as a renowned image stylist, and participated actively on the opening day of the exhibition, alongside Julie Sudiro and Rozita Rohaizad. "Pameran Ikon Fesyen Retro Saloma" opened on August 8, 2017 and closed on October 21, 2017; for the record, October 21 was also the date Saloma married P. Ramlee back in 1961. The exhibition, located at Gallery 2 in Muzium Negara, incorporated 3D Invisible Mounting System (utilising Interfacing Lining) in displaying selected dresses. The response from visitors has been overwhelming, as this was the first time an extensive exhibition on the couture of a celebrated performer was organised and opened to the public, as opposed to the usual heritage and bridal gowns collection. However, as mentioned earlier, the dresses exhibited were only a small portion of what Saloma's family members donated to the National Archives of Malaysia. A permanent solution to store and conserves the couture collection is in dire need, as these dresses may decay as time goes by.

\section{Saloma on the Silver Screen}

As stated earlier, Saloma branched out into acting when her singing career didn't take off as expected. She signed on as a performer for Nusantara Film Productions Limited, a socalled rival to Malay Film Productions Limited owned by Runme Shaw and Run Run Shaw. Coowned by Goh Hood Kiat, Ong Keng Hua, Ong Chin Hun, Koh Tin Kok, and Richard Lan Fu San, Nusantara Film Productions Limited managed to release only 11 films; Saloma appeared in 5 films directed by Nas Achnas and A. R. Tompel (Aman Ramli Jaafar, Saloma's first husband). Unfortunately, all films did not survive and went missing or out of print. Later, as her singing career began to take off, Saloma signed another contract with the aforesaid Malay Film Productions Limited, and appeared in movies either as an actress (Azimat, Adek-Ku, Empat Isteri, Kaki Kuda, and Seniman Bujang Lapok) or as a cameo performer (Saudagar Minyak Urat, Ibu Mertua-Ku, Labu dan Labi, Nasib Si Labu Labi, Love Parade, Melanchong Ka-Tokyo, and Tiga Abdul). When P. Ramlee moved to Kuala Lumpur and began his tenure at Setudio Merdeka, Saloma continued to act in a few films such as Ragam P. Ramlee, Sabaruddin Tukang Kasut, and Ahmad Albab, as well as making numerous cameo appearances in films such as Do Re Mi, Nasib Do Re Mi, Anak Bapak, Sesudah Suboh, Gerimis, Dr Rushdi, and Jangan Tinggal Daku. Simultaneously, she also became a playback singer for both studios (as well as a couple of films for Cathay-Keris Film Productions). Most of these songs were re-recorded for distribution under EMI labels such as Pathe, Parlophone and Columbia.

In the early 1980s, it was widely reported that Saloma would appear in two films: Malay Traders (to be directed by Sergio Goncharoff and co-produced by Idris Haji Ibrahim, Jacques Deerson, and Z\&Z Productions) and Ke Mana Hati Kanku Bawa (a proposed collaboration project between Sultan Idris Iskandar Al-Mutawakkil Alallahi Shah Ibni Almarhum Sultan Iskandar Shah Kaddasullah of Perak and Yusaini Amir, under a Bumiputra venture Cahaya Film Production Sendirian Berhad). Both films were scheduled to be released between 1981 and 1982; alas, nothing was materialised. Meanwhile, after a long absence, Saloma returned to her playback singing duty, this time with Filem Negara Malaysia where she sang the theme songs to Gelombang (1981); Bila Hati Telah Retak (1983). Bila Hati Telah Retak was her final appearance on film and billed as "a special guest star." Both songs from the Filem Negara Malaysia productions were composed by renowned songwriter, Ibrahim Bachik. In addition, she also performed two numbers in Serampang Tiga, a film produced by Indra Rekod's owners Zain and Zaharan, under the banner of Indra Film Productions. The two 
songs, "Kembara Rasa" (duet with S. Rossley) and "Jasa Perwira" (duet with Julie Sudiro), were composed by Kassim Masdor; both were later included in Saloma's final album Biduan Negara Saloma, albeit in different versions. In 1982, Saloma's vocalise performance was featured in the original score of Bukit Kepong, written by Inspector Abu Bakar Long ARMC, L(MUS) VCM, RMSM; her haunting voice can be heard in the film's final scenes.

Most of Saloma's appearances on films are still available - except for her films with Nusantara Film Productions Limited, and sporadic films from her Malay Film Productions heydays such as Melanchong Ka-Tokyo and Love Parade. Nevertheless, a proper documentation on Saloma's acting (in either lead or featured role) and playback singing in films is essential.

\section{Conclusion}

Even though Saloma was honoured with a regal and eminent title Biduan Negara, attempts in documenting her body of works and legacy have been erratic and lackadaisical. While the existence of Jalan Saloma and Pintasan Saloma can be viewed as titular tributes to the aforesaid Biduan Negara, as one of the prominent singers in Malaysia, it is disheartening that Saloma's full discography is not comprehensive. While the company formerly known as EMI Malaysia had been prolifically re-releasing her recordings from time to time, it is best for the current owner of all her recordings, Universal Music Malaysia, starts compiling the list of Saloma's catalogues dating from 1954. It is emboldening to see Saloma's selected recordings are made available on iTunes, Spotify, JOOX and YouTube, but more can be done to expose rarities from Saloma's vault. As most higher learning institutions in Malaysia are working extensively in research, perhaps Universal Music Malaysia may collaborate with any faculties of creative arts or performing arts, as well as academicians from creative industry management discipline in a collaboration for completing Saloma's list of discographies. Radio Televisyen Malaysia is also encouraged to be less bureaucratic in assisting prospective researchers in getting access to its programmes in the treasured vault in Angkasapuri. The National Archives of Malaysia, meanwhile, should be encouraged to start discussing with the Department of Museums Malaysia (Jabatan Muzium Malaysia) in turning the provisional "Saloma, Retro Fashion Icon" exhibition into a permanent staple in a space large enough to display Saloma's vast collection of couture. After all, not all singers in Malaysia are deserving of the aforesaid eminent title of Biduan Negara, and Saloma was proven to be one in a million.

\section{References}

Abdul Hamid, A. S. (1999). P. Ramlee: Erti yang sakti. Pelanduk Publications.

Asah, E. (1981). Saloma tunjuk cara baiki suara. Berita Harian. https://eresources.nlb.gov.sg/newspapers/Digitised/Article/beritaharian19811011-

1.2.37.2?ST $=1 \& A T=$ advanced $\& K=$ Saloma $\& K A=S a l o m a \& D F=01 \% 2 F 01 \% 2 F 1980 \& D T=3$ $1 \% 2 F 12 \% 2 F 1983 \& N P T=\& L=M a l a y \& C T A=\& Q T=$ saloma\&oref $=$ article

Kaur, S. (2020). Pintasan Saloma a boost to the city. New Straits Times. https://www.nst.com.my/property/2020/02/565138/pintasan-saloma-boost-city

Md Yusup, A. R. (2017). Glimpses of a legend. New Straits Times. https://www.nst.com.my/lifestyle/flair/2017/09/281852/glimpses-legend

Salleh, A. (1980). Sultan minta Saloma berlakon filem. Berita Harian. https://eresources.nlb.gov.sg/newspapers/Digitised/Page/beritaharian198003021.1.7?ST=1\&AT=search\&k=sultan\%20minta\%20saloma\&QT=sultan, minta,saloma\&or ef=article 
Salleh, A. J. (1981). Saloma kini kembali segar seperti dulu. Berita Harian. https://eresources.nlb.gov.sg/newspapers/Digitised/Article/beritaharian198106211.2.33.4?ST $=1 \& A T=$ advanced $\& K=S a l o m a \& K A=S a l o m a \& D F=01 \% 2 F 01 \% 2 F 1980 \& D T=3$ $1 \% 2 \mathrm{~F} 12 \% 2 \mathrm{~F} 1983 \& N P T=\& \mathrm{~L}=$ Malay $\& C T A=\& Q T=$ saloma\&oref=article

Salleh, A. J. (1982). Saloma kembali 'ligat'. Berita Harian. https://eresources.nlb.gov.sg/newspapers/Digitised/Article/beritaharian198204041.2.30.3.2 ?ST $=1 \& A T=$ advanced $\& K=S a l o m a \& K A=S a l o m a \& D F=01 \% 2 F 01 \% 2 F 1980 \& D T=$ $31 \% 2 F 12 \% 2 F 1983 \&$ Display=0\&NPT=\&L=Malay\&CTA=\&QT=saloma\&oref=article

Samad, A. F. (2011). Saloma. AF Cendana Publications.

Simon, M. (1981). Saloma berlakon dlm filem Inggeris. Berita Harian. https://eresources.nlb.gov.sg/newspapers/Digitised/Article/beritaharian198109091.2.39.1 ?ST $=1 \& A T=$ advanced $\& K=$ Saloma $\& K A=S a l o m a \& D F=01 \% 2 F 01 \% 2 F 1980 \& D T=3$ 1\%2F12\%2F1983\&Display=0\&NPT=\&L=Malay\&CTA=\&QT=saloma\&oref=article

Sirat, K. (1983). Saloma meninggal: Ramai yang terkejut. Berita Harian. https://eresources.nlb.gov.sg/newspapers/Digitised/Article/beritaharian198304261.2.8?ST $=1 \& A T=$ advanced $\& K=S a l o m a \& K A=S a l o m a \& D F=01 \% 2 F 01 \% 2 F 1980 \& D T=31 \%$ 2F12\%2F1983\&NPT=\&L=Malay\&CTA=\&QT=saloma\&oref=article 